\title{
The adipokine vaspin reduces apoptosis in human hepatocellular carcinoma (Hep-3B) cells, associated with lower levels of NO and superoxide anion
}

Magdalena Skonieczna ${ }^{1,2^{*}}$ (D) Dorota Hudy ${ }^{1,2}$, Tomasz Hejmo ${ }^{3}$, Rafal J. Buldak ${ }^{3}$, Małgorzata Adamiec ${ }^{1,2}$ and Michal Kukla ${ }^{4}$

\begin{abstract}
Background: Among adipose-derived factors, adipocytokines play roles as hormones and signaling mediators for apoptotic pathway. Among of them, vaspin, regulates the metabolism of adipose tissue itself as an endocrine organ, and stimulates adipocytes to maturation, differentiation, etc. Damaged adipocytes, present in obesity and hepatocellular carcinoma (HCC) respond with over-production of inflammatory cytokines. Such pro-inflammatory stimulation remains under adipokine control. Pro-inflammatory pathways are connected to oxidative stress and apoptosis, reported as co-existing with an elevated level of some adipokines in cancer cell lines. However, some hormones, such as vaspin, reduce apoptosis, have anti-inflammatory and anti-oxidative roles in cancer cell lines.

Methods: Hep-3B cells were cytometrically evaluated under vaspin treatment for reactive oxygen species (ROS) and apoptosiss induction. The statistical significant changes to the untreated controls was calculated by T-tests (indicated at value $p<0.05)$.

Results: Here we studied the production of reactive oxygen and nitrogen species in cells of HCC line Hep-3B after vaspin treatment. A decreased level of nitric oxide and superoxide anion $24 \mathrm{~h}$ after vaspin addition at $5 \mathrm{ng} / \mathrm{ml}$ was correlated with restricted, to the physiological level, apoptosis. A protective role of vaspin was displayed as enhanced cell viability and proliferation, which could be a poor prognostic in liver cancer.
\end{abstract}

Conclusions: Apoptosis was suppressed after vaspin treatment, together with low levels of nitric oxide and superoxide anions.

Keywords: Vaspin, Adipose tissue, Hepatocellular carcinoma, Oxidative stress, Apoptosis signaling pathway, Hep-3B cells

\section{Background}

Enhanced secretion of adipose-derived hormones termed adipokines or adipocytokines, like growth factors and pro-inflammatory cytokines, allows to focus on elements for studies of the pathogenesis of tumor growth, increased mobility and cell migration, and subsequently cancer metastasis $[1,2]$. The adipokines could play a significant role in regulation of cell growth, proliferation,

\footnotetext{
* Correspondence: magdalena.skonieczna@polsl.pl

'Systems Engineering Group, Silesian University of Technology, Institute of Automatic Control, 16 Akademicka Street, 44-100 Gliwice, Poland

${ }^{2}$ Biotechnology Centre, Silesian University of Technology, Krzywoustego 8 , 44-100 Gliwice, Poland

Full list of author information is available at the end of the article
}

cell cycle, angiogenesis and also tumor growth and metastases [3]. One of the adipokines, leptin, is expressed in colorectal tumors with a greater expression in more aggressive tumors [4]. Cell motility is one of the most important factors that can affect both cell migration and invasion in cancer. There is probably a molecular and regulatory role for adipokines, also in cancerogenesis, migration and cancer progression. The possible mechanisms which clarify the associations between obesity and cancers are based on the promoting of growth signaling, inflammation, vascular disorders and microenvironmental dysfunctions [5-7].

(c) The Author(s). 2019 Open Access This article is distributed under the terms of the Creative Commons Attribution 4.0 International License (http://creativecommons.org/licenses/by/4.0/), which permits unrestricted use, distribution, and reproduction in any medium, provided you give appropriate credit to the original author(s) and the source, provide a link to the Creative Commons license, and indicate if changes were made. The Creative Commons Public Domain Dedication waiver (http://creativecommons.org/publicdomain/zero/1.0/) applies to the data made available in this article, unless otherwise stated. 
Studies of the molecular mechanisms of actions of cytokines were done on a model cell line Hep-3B, originated from hepatoma [5]. This human HCC cell line has been reported as lacking a functional $p 53$ gene, so different physiological pathways, especially p53-dependent, could be defective or disturbed in that cell line [8]. Mutations of the $p 53$ gene are the most frequent in human cancers, also in hepatocellular carcinomas [9]. Lack of the $p 53$ gene also influences cellular death, e.g. apoptosis dependent on AKT/PTEN/FOXO4-pathways. Long-term hormonal treatments with visceral adipose tissue-derived vaspin presented a wide spectrum of activities for that molecule [10].

Aim of presented work, was to study one of the multiple modes of action of adipose tissue-derived hormones, an anti-apoptotic function of vaspin, and was examined in Hep-3B cells. Reactive oxygen species (ROS) were assessed with a particular emphasis on nitric oxide (NO), superoxide anion $\left(\cdot \mathrm{O}_{2-}\right)$, and overall ROS level estimated by $2^{\prime}$, 7 '-dichlorofluorescein diacetate (DCFH-DA) and a specific DNA-associated dye (CellROX Green). Oxidative stress, either induced by viral infections, inflammation, or external factors (eg ultraviolet or ionizing radiation), typically should result in cellular death through necrotic or apoptotic pathways. In p53 mutant cancer cell lines, this scheme is rather disrupted and cell death does not occur [9]. Cancer cell survival is promoted together with proliferation [9]. Some of the adipose tissue-derived hormones, like vaspin, protect p53 mutants against apoptosis activation [8], and the results presented in this study indicate a reduction of natural oxidative stress. Free radical scavenging in cells exposed to vaspin resulted in reduction of pro-oxidative apoptotic signaling pathways.

\section{Methods}

\section{Cells}

Human hepatocellular carcinoma (Hep-3B) cells from ATCC (Manassas, VA, USA) were a kind gift from Dr. Marek Rusin, from collections at the Maria SklodowskaCurie Memorial Cancer Center and Institute of Oncology, Gliwice, Poland. Cells were grown in DMEM-F12 medium (PAA, Poland) with 10\% (v/v) heat-inactivated fetal bovine serum (FBS) (EURx, Poland) and $10000 \mu \mathrm{g} / \mathrm{ml}$ streptomycin and 10000 units/ml penicillin) (Sigma-Aldrich, Germany), at $37{ }^{\circ} \mathrm{C}$ in a humidified atmosphere with $5 \% \mathrm{CO}_{2}$. For flow cytometric measurements cells were seeded in 6-well plates (Falcon) at $10^{5}$ cells/well in $2 \mathrm{ml}$ fresh medium and after $24 \mathrm{~h}$ the medium was replaced with fresh medium containing vaspin at $10,5,2.5,1.25,1$ or $0.1 \mathrm{ng} / \mathrm{ml}$. For MTS viability assays cells were seeded at $10^{4}$ cells/well in 96-well plates (Falcon) in $0.2 \mathrm{ml}$ medium and after 24 the medium was replaced with fresh medium containing vaspin. Untreated controls were prepared for flow cytometry and MTS assays.
Vaspin was from Enzo Life Sciences (cat. No. ALX201-360-C050) and dissolved in sterile PBS (PAA). Concentrated stock solutions $(0.05 \mathrm{mg} / \mathrm{ml})$ were stored at $-20{ }^{\circ} \mathrm{C}$ and working solutions were prepared in fresh growth medium.

\section{Apoptosis assays}

Cells exposed to vaspin for $24 \mathrm{~h}$ were washed and collected by trypsinization. Cells were centrifuged (0.4 rcf, $3 \mathrm{~min}$ ) and stained according to the Annexin-V apoptosis assay (Boncel et al., 2017). Cell pellets were dissolved in $50 \mu \mathrm{l}$ cold Annexin-V labeling buffer and then $2.5 \mu$ l of FITC-labeled Annexin-V antibody was added (BioLegend) followed by $10 \mu \mathrm{l}$ of propidium iodide (PI) solution $(100 \mu \mathrm{g} / \mathrm{ml}$; Sigma). After $20 \mathrm{~min}$ in darkness, $250 \mu \mathrm{l}$ of Annexin-V labeling buffer was added and the samples were incubated on ice and in the dark for $15 \mathrm{~min}$. Flow cytometric analysis (Aria III, Becton Dickinson) using the FITC configuration ( $488 \mathrm{~nm}$ excitation; emission: LP mirror 503, BP filter 530/30) and the PE configuration (547 nm excitation; emission: $585 \mathrm{~nm}$ ) was performed immediately and at least 10,000 cells were counted. Cells were classified as necrotic (PI positive and Annexin-V negative; late apoptotic (PI positive and Annexin-V positive); early apoptotic (PI negative and Annexin-V positive); or normal (PI negative and Annexin$\mathrm{V}$ negative) [11].

\section{MTS viability assays}

Cells were incubated with vaspin for 24,48 or $72 \mathrm{~h}$, washed three times with PBS (PAA), and $20 \mu \mathrm{l}$ of MTS solution (Promega) in $100 \mu \mathrm{l}$ PBS (PAA) were added to each well according to the producer protocol [12]. The plates were incubated for $2-4 \mathrm{~h}$ until the color in the control wells had changed from light yellow to brown. The absorbance of formazan produced by live cells was measured at $490 \mathrm{~nm}$ using a microplate spectrophotometer (Epoch; BioTek) and is expressed as means \pm SD from 3 experiments in triplicate and as fold changes of viability compared to untreated control cells.

\section{Cytometric measurements of reactive oxygen species and nitric oxide}

Overall ROS levels were measured by flow cytometry using specific dyes, 2',7'-dichlorofluorescin diacetate (DCFH-DA; Sigma) for reactive oxygen species (ROS), CellROX Green (Life Technologies) for superoxide anion $\left(\bullet \mathrm{O}_{2}-\right)$, or MitoSOX ${ }^{\mathrm{mm}}$ Red (Life Technologies) for mitochondrial superoxide and DAF-FM (Life Technologies) for nitric oxide (NO), as described previously $[13,14]$. DCFH-DA, a cell-permeable non-fluorescent probe, converts into the highly fluorescent $2^{\prime}, 7^{\prime}$-dichlorofluorescein (DCF) upon deacetylation by intracellular esterases and oxidation by ROS. CellROX Green is also a cell- 
permeable, non-fluorescent probe which becomes highly fluorescent in the presence of superoxide anions and then binds to double-stranded DNA, mainly in the nucleus. MitoSOX is oxidized by mitochondrial superoxide but not by other ROS or reactive nitric species (RNS) to produce red fluorescence. DAF-FM diacetate is cell-permeable and is deacetylated inside cells to DAF-FM, which is converted to a fluorescent benzotriazole when it reacts with NO.

For flow cytometric measurement of ROS and NO, $300 \mu \mathrm{l}$ of duplicate samples of cells in PBS were stained either with DCFH-DA $(30 \mu \mathrm{M})$, CellROX Green $(2.5 \mu \mathrm{M})$ for ROS detection, MitoSOX Red $(2.5 \mu \mathrm{M})$ for superoxide anions, or DAF-FM $(2.5 \mu \mathrm{M})$ for nitric oxide (NO). After incubation in darkness at $37^{\circ} \mathrm{C}$ for $30 \mathrm{~min}$ the cells were washed with PBS and kept in the dark for $15 \mathrm{~min}$ on ice (DCFH-DA and CellROX Green) or at room temperature (MitoSOX Red and DAF-FM). Fluorescence was measured using the FITC configuration for DCFH-DA, CellROX Green and DAF-FM or the PE configuration for MitoSOX Red [11]. At least 10,000 cells were counted. The results were analyzed using the free software FlowingSoftware 2.5.0 (Perttu Terho, Turku Centre for Biotechnology, University of Turku, Finland) and are presented as mean fluorescence.

\section{Statistical analyses}

Results are presented as means \pm SD from three separate experiments, performed in six replicates for cytotoxicity and triplicates for cytometric assays. The experimental means were compared to those for untreated cells collected in parallel. The results were analyzed using MS Office ver. 2.5.0 and MS Excel 2007. Statistical significance vs the control was calculated by T-tests and $p<$ 0.05 is indicated by*.

\section{Results}

After growth of Hep-3B cells in the presence of vaspin the fraction of apoptotic cells was reduced (Fig. 1a, b and $\mathrm{c}$ ). Within the apoptotic fraction, apoptosis assays together with DNA staining distinguished necrotic from apoptotic cells and early from late apoptosis [11]. In control cultures the apoptotic fraction did not exceed $10 \%$ of the total cells for early and $15 \%$ for late apoptosis, and necrosis was almost undetectable (Fig. 1c). Vaspin at $10 \mathrm{ng} / \mathrm{ml}$ reduced the frequency of total apoptotic cells significantly after $24 \mathrm{~h}$, showing that a mechanism protecting cells against apoptosis was activated.

This conclusion was supported by assays of cell proliferation and survival. Compared to untreated control cells, the best viability was observed at $48 \mathrm{~h}$ (Fig. 2a). After $24 \mathrm{~h}$ with vaspin a slightly increase of viability was observed at doses of $5-10 \mathrm{ng} / \mathrm{ml}$, and at $1 \mathrm{ng} / \mathrm{ml}$ the viability increased almost 1.5 -fold in comparison to the control (Fig. 2b).

The activation of apoptosis is often correlated with cellular oxidative stress, either internally or externally induced. Normal functions of cells cause physiological production of free radicals, for example superoxide anions by mitochondrial complexes I and III of the cytochrome chain [15]. Free radicals are also present as signaling molecules produced by enzymes such as the seven membrane-bound NADPH-dependent oxidases (Nox1-5 and Duox1-2) [16, 17]. Among short-lived molecules, nitric oxide $(\mathrm{NO})$ is an important signaling molecule [14].

Cytometric measurements showed fluctuations of NO level after $24 \mathrm{~h}$ exposure to vaspin. At $2.5 \mathrm{ng} / \mathrm{ml}$ of vaspin NO increased significantly compared to the untreated control (Fig. $3 \mathrm{a}$ and b), while at $5 \mathrm{ng} / \mathrm{ml}$ its level decreased. A second, significant increase in the level was induced by vaspin at $10 \mathrm{ng} / \mathrm{ml}$ for $24 \mathrm{~h}$ (Fig. 3b). These fluctuations seemed to be crucial for apoptotic pathway inhibition (Fig. 1) and enhanced viability and proliferation (Fig. 2). The level of superoxide anion, measured using the specific probe MitoSOX, decreased after $24 \mathrm{~h}$ of incubation with $2.5-5 \mathrm{ng} / \mathrm{ml}$ vaspin (Fig. $3 \mathrm{c}$ and d). The physiological level of superoxide anion was rather stable at other vaspin concentrations, and comparable to the control. At the highest dose of vaspin $(10 \mathrm{ng} / \mathrm{ml})$ the level of $\bullet \mathrm{O}_{2}$ - returned to a value slightly higher than the control (Fig. 3d).

Flow cytometry measurements of $\mathrm{NO}$ and $\cdot \mathrm{O}_{2}$ - indicated on a strong relationship between the low levels observed at $5 \mathrm{ng} / \mathrm{ml}$ vaspin and inhibition of apoptosis (Figs. 1, 2). These low levels were significant in comparison to those in untreated controls during $24 \mathrm{~h}$ of incubation in the same conditions (Fig. 3). So, inhibition of apoptosis at $5 \mathrm{ng} / \mathrm{ml}$ of vaspin is related to decreased levels of signaling molecules such as $\mathrm{NO}$ and $\bullet \mathrm{O}_{2^{-}}$(Fig. 3). Recovery of $\mathrm{NO}$ and $\cdot \mathrm{O}_{2}$ - to physiological levels, and even an elevation over the control level at higher doses of vaspin, did not change its protective activity. There appears to be a switch which is turned on at lower doses of vaspin $(2.5 \mathrm{ng} / \mathrm{ml})$ but activated by higher than control levels of $\mathrm{NO}$, and at lower doses of vaspin $(1 \mathrm{ng} / \mathrm{ml})$ is activated by higher than control levels of $\bullet \mathrm{O}_{2^{-}}$(Fig. 3). Once initiated, an anti-apoptotic cascade is maintained at higher vaspin concentrations $(5-10 \mathrm{ng} / \mathrm{ml}$ ) (Figs. 1 and 3). The lowest levels of $\mathrm{NO}$ and $\bullet \mathrm{O}_{2}$ - at $5 \mathrm{ng} / \mathrm{ml}$ of vaspin inhibited apoptosis efficiently (Figs. 1 and 3).

To better understand the role of ROS in induction/inhibition of the apoptosis pathway, further measurements of ROS were performed. Specific staining of ROS using the probes DCFH-DA and CellROX Green did not detect significant changes in free radicals level. At the lowest vaspin dose $(0.1 \mathrm{ng} / \mathrm{ml})$ the ROS level after $24 \mathrm{~h}$ 


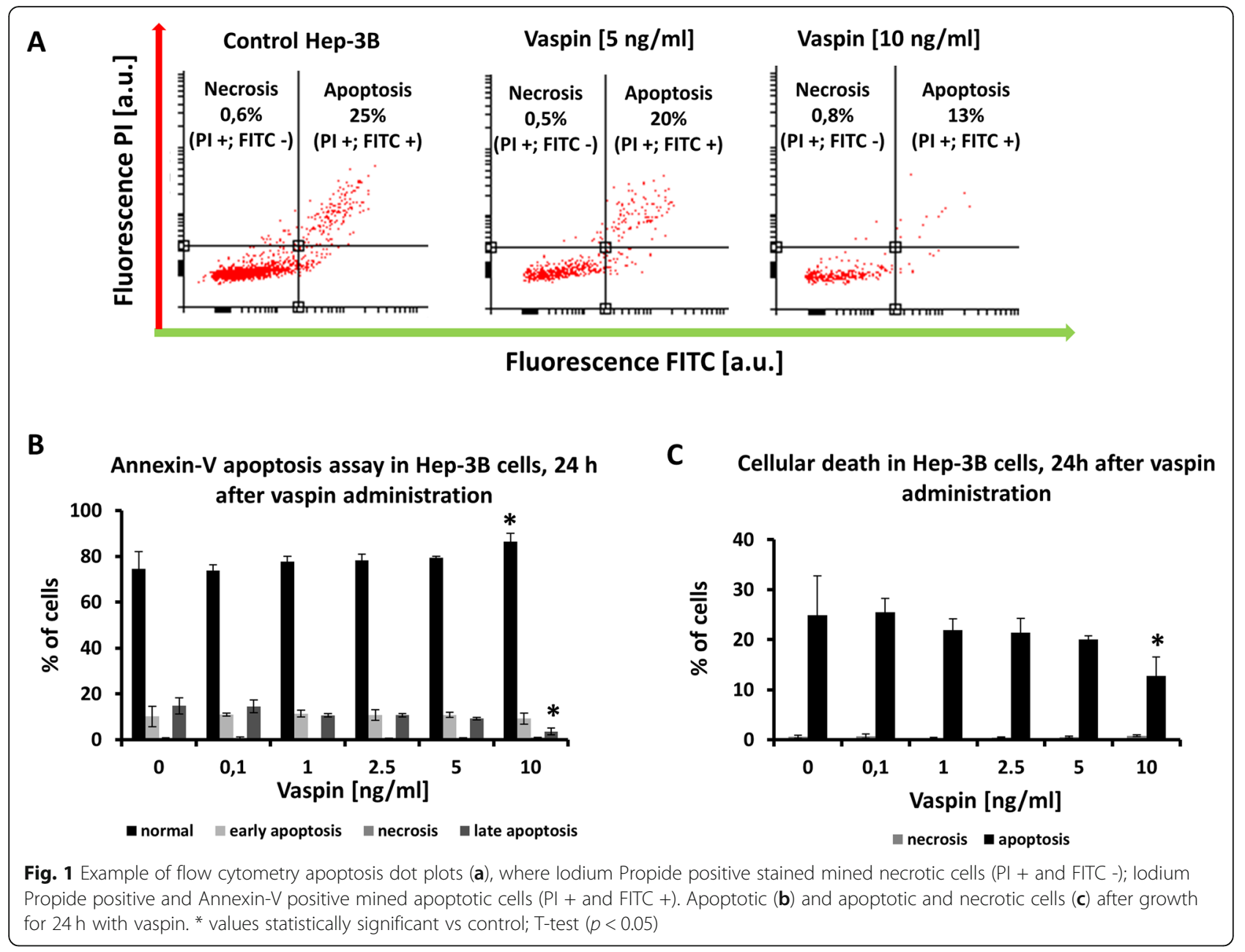

of incubation decreased only slightly in comparison to untreated controls (Fig. 4). At $1-10 \mathrm{ng} / \mathrm{ml}$ of vaspin the level of ROS recovered to the control level as assayed by either probe (Fig. 4). Flow cytometry measurements discriminated between overall and DNA-associated ROS, but did not explain the role of global ROS in cells after hormonal exposure. The level of ROS was stable during $24 \mathrm{~h}$ of incubation, without any spectacular changes related to the vaspin dose (Fig. 4). Inhibition of the apoptosis pathway after vaspin treatment was connected to lowered $\mathrm{NO}$ and $\bullet \mathrm{O}_{2}$ - levels, rather than to the stable level of ROS overall (Figs. 1, 3 and 4).

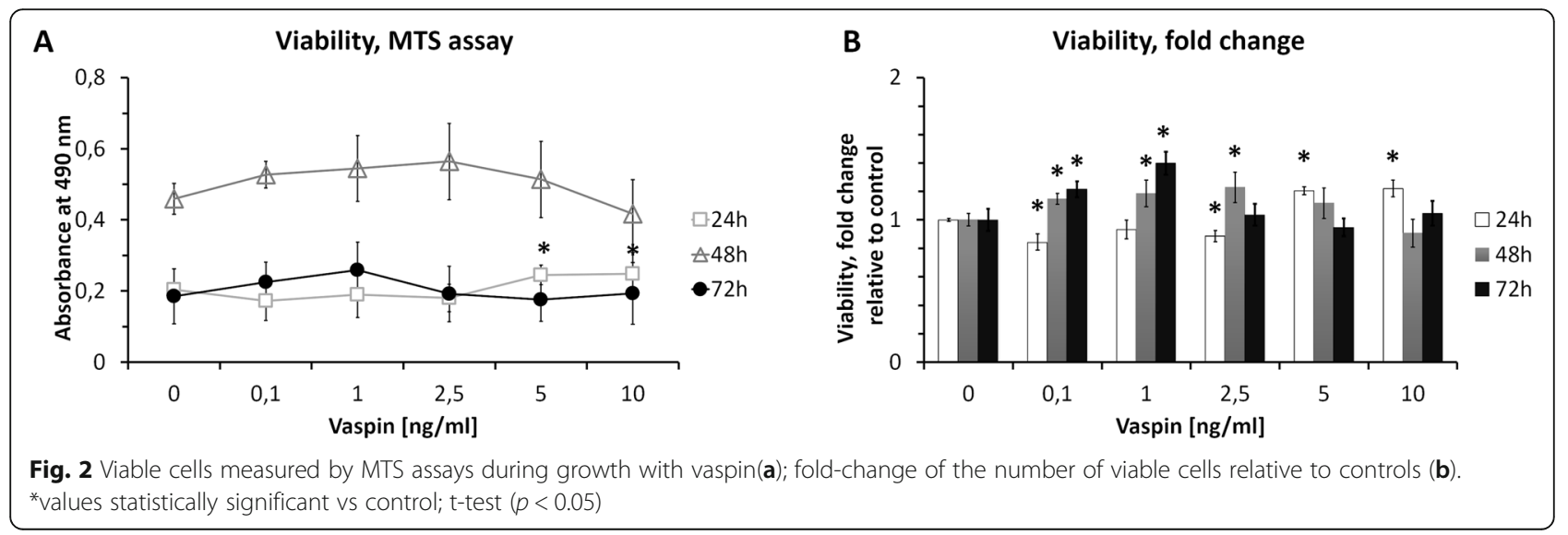




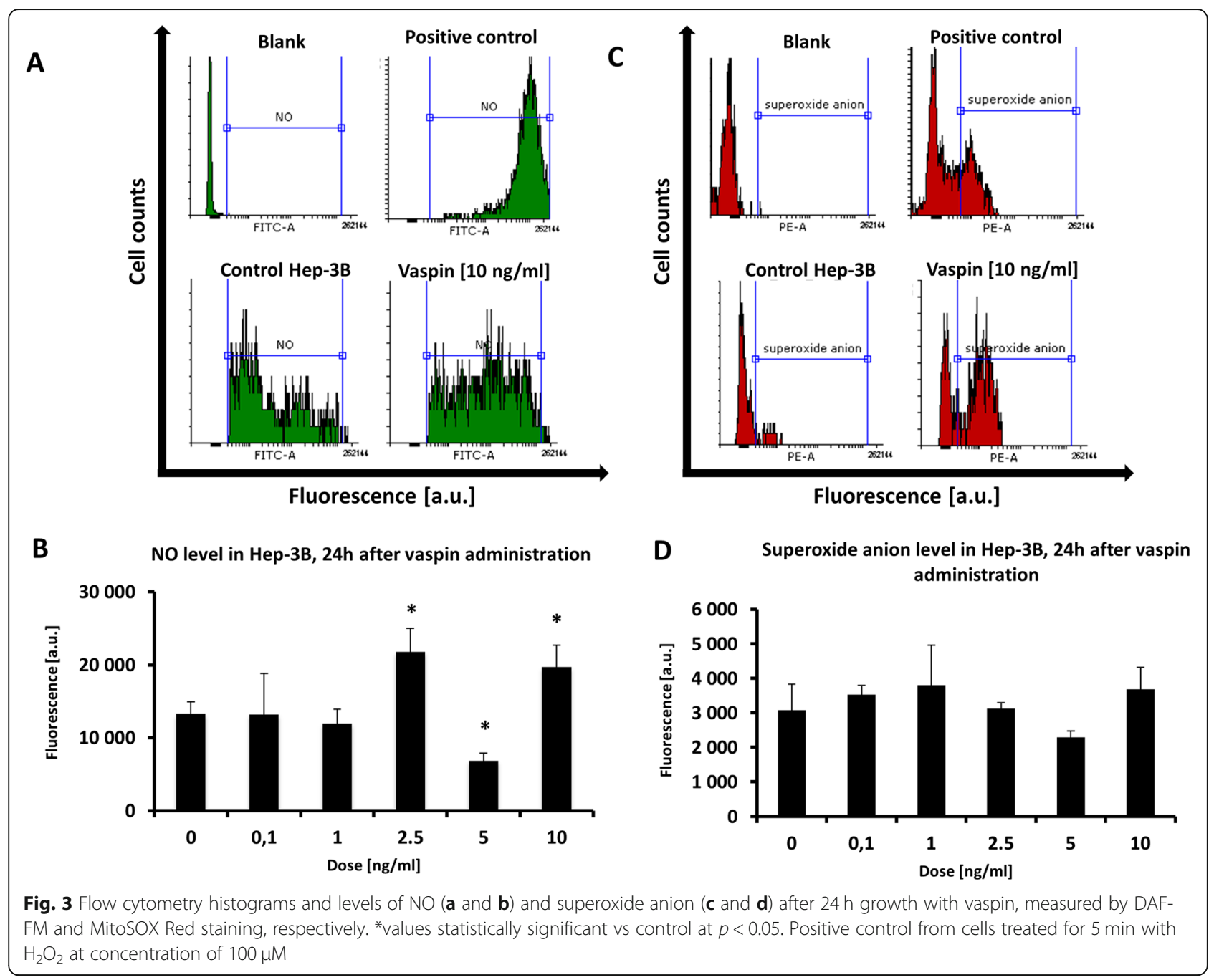

\section{Discussion}

Processes such as improved viability, proliferation, and survival after inhibition of apoptosis in cancer cells depend on external and internal cross-talk between signaling pathways and many factors and hormones, including vaspin $[10,18-20]$. The present studies were done to better understand the multiple roles of vaspin, an adipokine derived from adipose tissue. Vaspin protected human hepatocellular carcinoma cells against oxidative stress and apoptosis. Reactive oxygen species, nitric oxide,
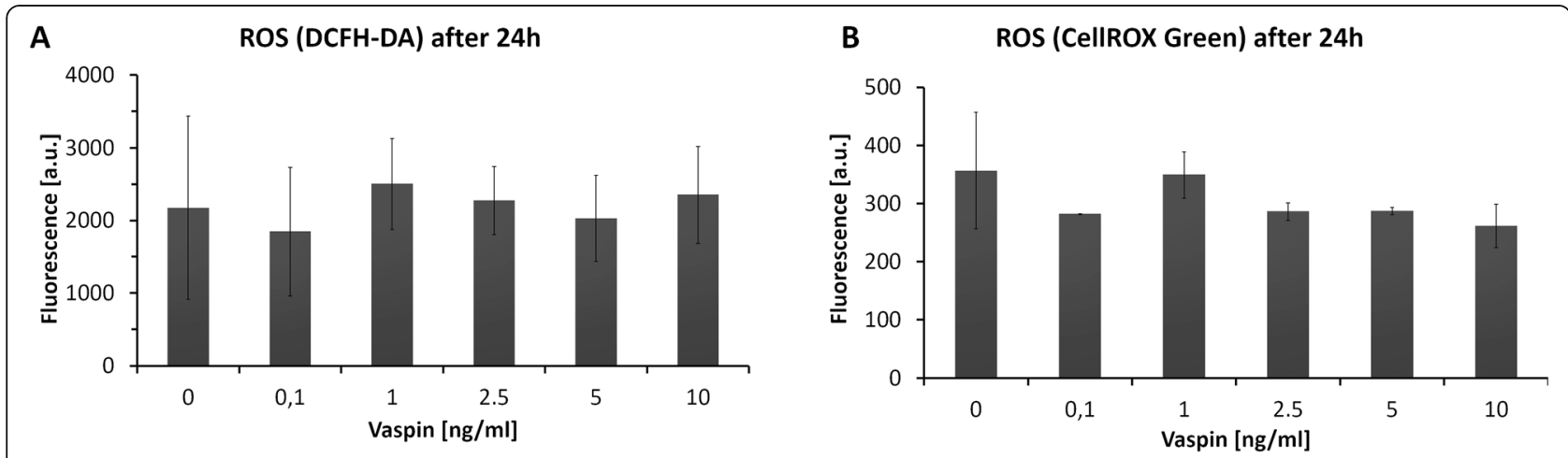

Fig. 4 Levels of intracellular ROS after growth for $24 \mathrm{~h}$ with vaspin assayed by DCFH-DA (a) or by CellROX Green (b). Experimental values were not significantly different from controls; T-test $(p<0.05)$ 
and superoxide anion appear to be involved in this anti-apoptotic activity.

\section{Adipose tissue delivers regulatory factors}

In the human body, adipose tissue plays the role of a systemic endocrine organ through whole-body energy regulation and glucose homeostasis [21]. They produce numerous bioactive factors such as adipokines which play roles of cytokines in metabolic disorders including obesity and related diseases, and since two decades visfatin, leptin, hepcidin, adiponectin, vaspin, apelin, chemerin, omentin, and others have been discovered and extensive studied [21-24]. Adipose tissue is known as brown (BAT) and white (WAT), associated respectively with thermoregulation and obesity in animals and adipocyte maturation and regulatory factor delivery [25]. Connections within adipose tissue depend on the regulatory factors which they produce (hormones, cytokines) or on processes occurring in the body (viral infections, inflammation) (Fig. 5). External factors delivered with nutrition via the digestive tract also interact with adipose tissue, directly or through induced processes (e.g. liver injury and inflammation after alcohol intake or heavy metal pollution) [3, 26-28]. An interaction with adipose tissue-delivered factors seems to be crucial and very important for pathogenic processes such as human hepatocellular carcinoma development and progression (Fig. 5).
Vaspin enhances hepatoma cell viability and proliferation The protective activity of vaspin on Hep-3B cells was confirmed by Annexin- $\mathrm{V}$ apoptosis assays, where apoptosis was suppressed in a dose-depended manner (Fig. 1). The fraction of normal cells (PI negative and Annexin-V negative) in the population increased to almost $100 \%$ at $5-10$ $\mathrm{ng} / \mathrm{ml}$ vaspin (Fig. 1), and viability measured by MTS assays increased (Fig. 2). Some adipokines are known as protectors of cancer cells because they play a role of promoters in cancer cell progression and enhance metastasis through stimulation of cell proliferation and migration [4]. Adiposederived hormones, cytokines stimulating inflammatory process, and growth factors are responsible for the pathogenesis of tumor growth [4]. Only a few studies suggest a stimulatory effect of vaspin on proliferation of cancer cells $[4,29,30]$. An elevated vaspin level was reported in colorectal cancer [31] but a lower level in endometrial cancer [32]. Vaspin also increased the proliferation of rat insulinoma cells [33]. Angiogenesis, new blood vessels formation, seems to be essential in cancer development and progression. Vaspin was positively related to intensity of angiogenesis in chronic hepatitis [24] via association of adipokines with angiogenesis. The main risk factor of $\mathrm{HCC}$ in chronic liver diseases is advanced fibrosis/cirrhosis, which is strictly associated with angiogenesis intensity [7, 34]. Vaspin serum levels and mRNA liver expression were found to be increased in patients with advanced fibrosis or cirrhosis in

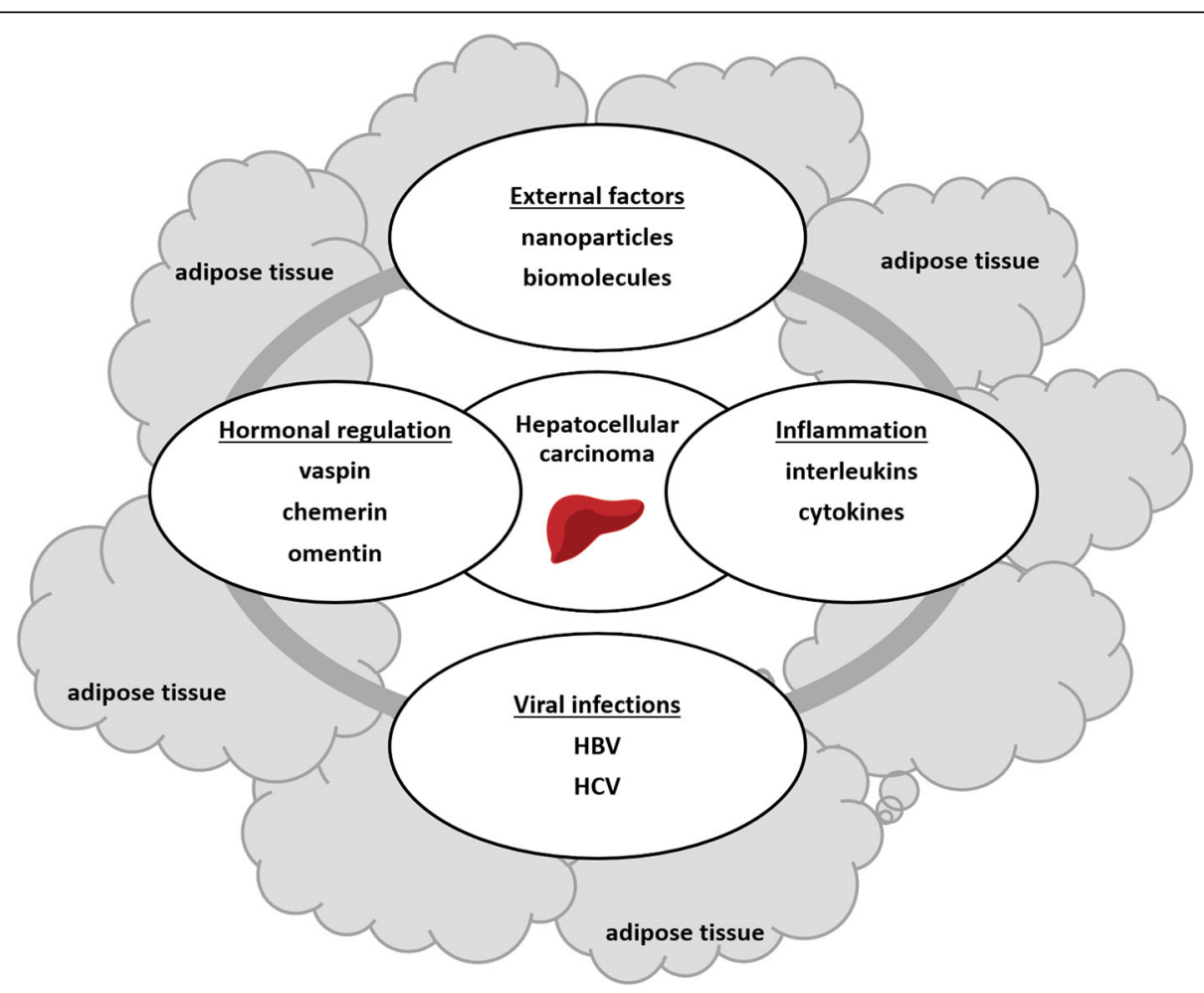

Fig. 5 Interactions between natural and artificial agents (viruses, hormones, biomolecules, and nanoparticles) in liver cancer development 
the course of chronic hepatitis [35, 36]. Pointing to these results, vaspin plays pivotal role in HCC development. Increased vaspin levels and expression in advanced liver disease may protect cancer cells against apoptosis and facilitate their proliferation.

\section{Role of adipokines in regulating oxidative stress}

Physiological oxidative stress results from endogenous processes like mitochondrial oxidative phosphorylation and the electron transport chain, lipid $\beta$-oxidation, peroxisome activity, and protein degradation, and signal transduction via free radicals which produce reactive oxygen and nitrogen species in living cells $[37,38]$. Imbalance in production and scavenging of free radical leads to numerous metabolic disorders including cancer stem cell activation and cancer development (reviewed in [39]). Adipose tissue produces factors such as visfatin which impact on free radical levels through influencing the enzymatic systems responsible for ROS production or inactivation [4, 40-42]. In HCT116 colorectal cancer cells oxidative stress was decreased by another adipokine, visfatin, and ROS levels decreased, but apoptosis increased and viability was reduced, so there visfatin showed pro-apoptotic activity uncorrelated with the ROS level [41]. On the other hand, in Me45 melanoma cells visfatin increased oxidative stress and ROS due to its pro-inflammatory action in increasing production of interleukins IL-6 and IL-8 [42]. Studies on Huh-7 liver HCC cells showed association between cell migration and elevated ROS level via TNF- $\alpha$-activated NF- $\mathrm{kB}$ signaling [43]. The pro-oxidative activity of vaspin was tested in human endothelial EA.hy926 cells, and unlike visfatin it protected them from inflammation by inhibiting NF-kB signaling [20]. In rodents, vaspin inhibited TNF- $\alpha$-induced ROS generation in rat vascular smooth muscle cells and showed anti-oxidant protection [19].
Although in Hep-3B cells no significant elevation of global ROS level during $24 \mathrm{~h}$ of vaspin treatment was observed in our study (Fig. 4) the role of particular free radicals and signaling molecules, $\mathrm{NO}$ and $\boldsymbol{O}_{2^{-}}$, appeared to be important in modulating apoptotic pathways. After $24 \mathrm{~h}$ of vaspin treatment the NO level fluctuated significantly in a dose-dependent manner (Fig. 3), but oxidative stress was rather weak this might be crucial for limiting apoptosis. Superoxide anion levels also fluctuated, with a minimum at $5 \mathrm{ng} / \mathrm{ml}$ of vaspin. The decreased level of both $\mathrm{NO}$ and $\cdot \mathrm{O}_{2^{-}}$at $5 \mathrm{ng} / \mathrm{ml}$ of vaspin resulted rather from suppression of physiological oxidative processes (Fig. 3). Resveratrol was reported to be an antioxidant in rat adipose tissue in type 2 diabetes because of vaspin gene down-regulation, that mined vaspin absence resulted with oxidative stress reduction [44]. The explanation for vaspin's impact on mitochondrial activity remains unclear, however, reduced production of superoxide anions was observed in our study (Fig. 3). The role of NO in vaspin-treated hepatoma cells should be rather explained as a pro-inflammatory signaling molecule. Modulation of its level appeared to result from activation of inflammation processes and their reduction after vaspin treatment (Fig. 3). Consequence for that could be also elevated pro-inflammatory cytokines production and vaspin inhibited that inflammatory process $[18,20,45]$. NO was correlated to the serum vaspin level in type 2 diabetes patients with nephropathy, where vaspin had a stimulatory effect through the activation of NO synthase [46]. We conclude that in Hep-3B cells an elevated level of vaspin results in modulation of the level of $\mathrm{NO}$ and $\bullet \mathrm{O}_{2^{-}}$, with a significant depression at $5 \mathrm{ng} / \mathrm{ml}$ of vaspin (Fig. 3). In consequence, mitochondrial activity is reduced because the level of superoxide anion decreases below the control value. Generally, in Hep-3B cells vaspin reduced the physiological level of oxidative stress (Fig. 4) but did not influenced it

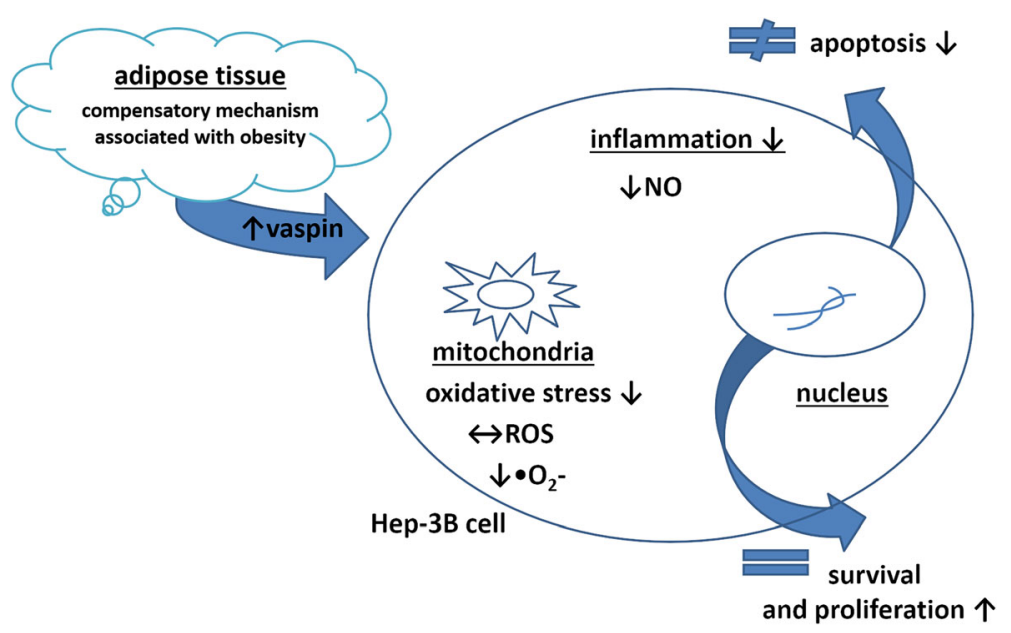

Fig. 6 Compensatory mechanisms associated with obesity and the anti-apoptotic and protective actions of vaspin in Hep-3B cells 
greatly. Reduction of ROS, with specific reduction of $\mathrm{NO}$ and $\bullet \mathrm{O}_{2^{-}}$, could restrict pro-inflamatory processes in cancer cells leading to better viability and proliferation (Figs. 1, 2) [47].

\section{Vaspin down-regulates apoptotic pathways in Hep-3B cells}

Our observations on the effects of vaspin on Hep-3B cells can be summarized as a restriction of apoptosis resulting from limitation of mitochondrial free radicals, especially superoxide anions (Fig. 3). A decreased level of NO results in an anti-inflammatory effect after vaspin treatment at $5 \mathrm{ng} / \mathrm{ml}$ (Fig. 3). Perhaps, pro-apoptotic signals in the canonical mitochondrial apoptosis pathway are suppressed by vaspin, and lower levels of ROS and NO are correlated with inhibition of cell death (Figs. 1 and 4). All ROS-dependent pathways should be under particular consideration, especially in HCC, including the p53-null Hep-3B cell line. In p53 mutants also receptors for apoptosis mediators, such as NF- $\mathrm{kB}, \mathrm{Bcl}-2$ or $\mathrm{Bcl}-\mathrm{XL}$ could be disrupted and apoptosis propagation stopped [48]. Vaspin could be a good mediator for antiapoptotic and anti-oxidative status influenced by lowered level of nitric oxide and superoxide anion. A different role for vaspin was suggested in patients with nonalcoholic fatty liver disease, where a chronic inflammatory state was observed. Although the vaspin serum level was low the pro-inflammatory cytokines level was elevated $[49,50]$. Moreover, vaspin levels increased in definite nonalcoholic steatohepatitis when compared to simple steatosis and in patients with hepatocyte ballooning, which may reflect oxidative stress and mitochondrial disfunction in hepatocytes [7]. The role of vaspin, either anti/pro-inflammatory, anti/pro-oxidative, or anti/pro-apoptotic is still unclear, but in Hep-3B cells it is rather protective (Fig. 6). Elevated serum concentrations of vaspin are associated with obesity and impaired insulin sensitivity in humans and it has therefore been postulated that increased vaspin expression and secretion could represent a compensatory mechanism associated with obesity, severe insulin resistance, and type 2 diabetes [51].

\section{Conclusions}

Apoptosis was suppressed after vaspin treatment, together with low levels of nitric oxide and superoxide anions.

\footnotetext{
Abbreviations

AKT: Serine/Threonine Kinase; BAT: Brown adipose tissue; DCFH-DA: 2',7'dichlorofluorescein diacetate; Duox: dual NADPH-dependent oxidases; FBS: Fetal bovine serum; FOXO4: Forkhead box protein O4; HCC: Hepatocellular carcinoma; Hep-3B: Human hepatocellular carcinoma; NF-kB: Nuclear factor kappa-light-chain-enhancer of activated B cells; NO: Nitric oxide; Nox: NADPH-dependent oxidases; PI: Propidium iodide; PTEN: Phosphatase and tensin homolog; ROS: Reactive oxygen species; TNFa: Tumor necrosis factor alfa; WAT: White adipose tissue
}

\section{Acknowledgments}

Dr. Marek Rusin is acknowledged for his kind gift of Hep-3B cells.

\section{Authors' contributions}

MS conceived, designed and carried out the experiments, analyzed data and wrote the paper. DH assisted in MTS assays and analyzed data. MA helped in cultivating cells. TH assisted in flow cytometric assays. RB and MK were involved in revising the paper's important content. All authors read and approved the final manuscript.

\section{Funding}

This work was supported by the Polish National Science Center, grant UMO2015/19/B/ST7/02984 (MS, DH and MA were supported for experimental and publication costs). MS, DH and MA made analysis and calculations using the Ziemowit computational cluster (http://www.ziemowit.hpc.polsl.pl) funded by the EU Innovative Economy Program (POIG) project 02.01.00-00-166/08 (BIO-FARMA) and expanded under the POIG project 02.03.01-00-040/13 (Syscancer). Experiments, interpretation of data and writing the manuscript by MS, DH and MA were performed in the Silesian BIO-FARMA - Bioinformatics Laboratory and the Biotechnology Centre of the Silesian University of Technology (POIG.02.01.00-00-166/08 project).

\section{Availability of data and materials}

The datasets used and analyzed during the current study are available from the corresponding author on reasonable request.

Ethics approval and consent to participate

Not applicable

\section{Consent for publication}

Not applicable

\section{Competing interests}

The authors declare that they have no competing interests.

\section{Author details}

${ }^{1}$ Systems Engineering Group, Silesian University of Technology, Institute of Automatic Control, 16 Akademicka Street, 44-100 Gliwice, Poland.

${ }^{2}$ Biotechnology Centre, Silesian University of Technology, Krzywoustego 8, 44-100 Gliwice, Poland. ${ }^{3}$ Department of Biochemistry, Medical University of Silesia, School of Medicine with the Division of Dentistry, Jordana 19, 41-808 Zabrze, Poland. ${ }^{4}$ Department of Gastroenterology and Hepatology, School of Medicine in Katowice, Medical University of Silesia, Medyków 14, 40-752 Katowice, Poland.

Received: 17 July 2018 Accepted: 29 August 2019

Published online: 11 September 2019

\section{References}

1. Libri V, Miesen P, Van Rij RP, Buck AH. Regulation of microRNA biogenesis and turnover by animals and their viruses. Cell Mol Life Sci. 2013;70(19): 3525-44.

2. Bossert N, De Bruin D, Götz M, Bouwmeester D, Heinrich D. Fluorescencetunable ag-DNA biosensor with tailored cytotoxicity for live-cell applications. Sci Rep. 2016;6:37897.

3. Li H, Bai E, Zhang Y, Jia Z, He S, Fu J. Role of Nampt and Visceral Adiposity in Esophagogastric Junction Adenocarcinoma. J Immunol Res. 2017;2017: 39706057 pages.

4. Booth A, Magnuson A, Fouts J, Foster M. Adipose tissue, obesity and adipokines: role in cancer promotion. Horm Mol Biol Clin Investig. 2015; 21(1):57-74

5. Hiron M, Daveau M, Arnaud P, Bauert J, Lebreton J-P. The human hepatoma Hep3B cell line as an experimental model in the study of the long-term regulation of acute-phase proteins by cytokines. Biochem J. 1992;287:255-9.

6. World Cancer Research Fund/American Institute for Cancer Research. Food, Nutrition, Physical Activity, and the Prevention of Cancer: a Global Perspective. Washington, DC: AICR; 2007.

7. Kukla M, Zwirska-Korczala K, Gabriel A, Waluga M, Warakomska I, Szczygiel B, Berdowska A, Mazur W, Wozniak-Grygiel E, Kryczka W. Chemerin, vaspin and insulin resistance in chronic hepatitis C. J Viral Hepat. 2010;2010(17):661-7. 
8. Liou AT, Chen MF, Yang CW. Curcumin Induces p53-Null Hepatoma Cell Line Hep3B Apoptosis through the AKT-PTEN-FOXO4 Pathway. Evid-Based Compl Alt. 2017:2017:4063865 12 pages.

9. Zhou W, Hwang PM, Dou Z, Long J, Marchenko ND, Alexandrova EM. Mutant p53 - heat shock response oncogenic cooperation: a new mechanism of cancer cell survival oncogenic functions of mutant p53. Front Endocrinol. 2015;6:53 7 pages.

10. Liu Y, Xu F, Pei H-X, Zhu X, Lin X, Song C-Y, Liang Q-H, Liao E-Y, Yuan L-Q. Vaspin regulates the osteogenic differentiation of MC3T3-E1 through the PI3K-Akt/miR-34c loop. Sci rep-UK. 2016;6:25578.

11. Czerwińska K, Golec M, Skonieczna M, Palion-Gazda J, Zygadło D, SzlapaKula A, Krompiec S, Machura B, Szurko A. Cytotoxic gold (III) complexes incorporating 2,2':6',2"-terpyridine ligand framework - the impact of the substituent in 4'-position of terpy ring. Dalton Trans. 2017;46(10):3381-92.

12. Boncel SB, Pluta A, Skonieczna M, Gondela A, Maciejewska B, Herman AP, Jędrysiak RG, Budniok S, Komędera K, Błachowski A, Walczak KZ. Hybrids of Iron-Filled Multiwall Carbon Nanotubes and Anticancer Agents as Potential Magnetic Drug Delivery Systems : In Vitro Studies against Human Melanoma, Colon Carcinoma, and Colon Adenocarcinoma. J. Nanomater. 2017;2017:1262309 13 pages.

13. Skonieczna M, Cieslar-Pobuda A, Saenko Y, Foksinski M, Olinski R, Rzeszowska-Wolny J, Wiechec E. The impact of DIDS induced inhibition of voltage-dependent anion channels (VDAC) on cellular response of lymphoblastoid cells to ionizing radiation. Med Chem. 2017;13(5):477-83.

14. Saenko Y, Cieslar-Pobuda A, Skonieczna M, Rzeszowska-Wolny J. Changes of reactive oxygen and nitrogen species and mitochondrial functioning in human K562 and HL60 cells exposed to ionizing radiation. Radiat Res, 2013;180(4):360-6.

15. Finkel T. Signal transduction by reactive oxygen species. J Cell Biol. 2011; 194:7-15.

16. Brown DI, Griendling KK. Nox proteins in signal transduction. Free Radic Biol Med. 2009:47:1239-53.

17. Aguirre J, Lambeth JD. Nox enzymes from fungus to fly to fish and what they tell us about Nox function in mammals. Free Radic Biol Med. 2010;49:1342-53.

18. Qi D, Wang D, Zhang C, Tang X, He J, Zhao Y, Deng W, Deng X. Vaspin protects against LPS-induced ARDS by inhibiting inflammation, apoptosis and reactive oxygen species generation in pulmonary endothelial cells via the Akt/GSK-3ß pathway. Int J Mol Med. 2017;40(6):1803-17.

19. Phalitakul S, Okada M, Hara Y, Yamawaki H. Vaspin prevents TNF-a-induced intracellular adhesion molecule-1 via inhibiting reactive oxygen speciesdependent NF-KB and PKCO activation in cultured rat vascular smooth muscle cells. Pharmacol Res. 2011;64(5):493-500.

20. Liu S, Dong Y, Wang T, Zhao S, Yang K, Chen X, Zheng C. Vaspin inhibited proinflammatory cytokine induced activation of nuclear factor-kappa B and its downstream molecules in human endothelial EA.hy926 cells. Diabetes Res Clin Pract. 2014;103(3):482-8.

21. Luo L, Liu M. Adipose tissue in control of metabolism. J Endocrinol. 2016; 231:R77-99.

22. Lago F, Gomez R, Gomez-Reino JJ, Dieguez C, Gualillo O. Adipokines as novel modulators of lipid metabolism. Trends Biochem Sci. 2009;34:500-10.

23. Andrade-Oliveira V, Camara NO, Moraes-Vieira PM. Adipokines as drug targets in diabetes and underlying disturbances. J Diabetes Res. 2015;2015: 68161211 pages.

24. Kukla M, Mazur W, Bułdak RJ, Zwirska-Korczala K. Potential role of leptin, adiponectin and three novel Adipokines - Visfatin, Chemerin and Vaspin - in chronic hepatitis. Mol Med. 2011;17(11-12):1.

25. Giralt $\mathrm{M}$, Villarroya $F$. White, brown, beige/brite: different adipose cells for different functions? Endocrinology. 2013;154(9):2992-3000.

26. Hui E, Xu A, Yang HB, Lam KSL. Obesity as the common soil of nonalcoholic fatty liver disease and diabetes: role of adipokines. J Diabetes Investig. 2013;4(5):413-25.

27. Marra F, Bertolani C. Adipokines in liver diseases. Hepatology. 2009;50(3): 957-69.

28. Brenner C, Galluzzi L, Kepp O, Kroemer G. Decoding cell death signals in liver inflammation. J Hepatol. 2013;59(3):583-94.

29. Erdogan S, Sezer S, Baser E, Gun-Eryilmaz O, Gungor T, Uysal S, Yilmaz FM. Evaluating vaspin and adiponectin in postmeno-pausal women with endometrial cancer. Endocr Relat Cancer. 2013;20(5):669-75.

30. Fazeli MS, Dashti H, Akbarzadeh S, Assadi M, Aminian A, Keramati MR, Nabipour I. Circulating levels of novel adipocy- tokines in patients with colorectal cancer. Cytokine. 2013;62:81-5.
31. Harwood HJ Jr. The adipocyte as an endocrine organ in the regulation of metabolic homeostasis. Neuropharmacology. 2012;63:57-75.

32. McCullough ML, Patel AV, Patel R, Rodriguez C, Feigelson HS, Bandera EV, Gansler T, Thun MJ, Calle EE. Body mass and endometrial cancer risk by hormone replacement therapy and cancer subtype. Cancer Epidemiol Biomark Prev. 2008;17:73-9.

33. Liu S, Li X, Wu Y, Duan R, Zhang J, Du F, Zhang Q, Li Y, Li N. Effects of vaspin on pancreatic $\beta$ cell secretion via PI3K/Akt and NF-KB signaling pathways. PLoS One. 2017;12(12):1-20.

34. Gabriel A, Kukla M, Wilk M, Liszka L, Petelenz M, Musialik J. Angiogenesis in chronic hepatitis $C$ is associated with inflammatory activity grade and fibrosis stage. Pathol Res Pract. 2009;205(2009):758-64.

35. Kukla M, Waluga M, Sawczyn T, Berdowska A, Kajor M, Boryczka G, Stygar D, Gabriel A, Zwirska-Korczala K, Hartleb M. (2012) serum vaspin may be a good indicator of fibrosis in chronic hepatitis $\mathrm{C}$ and is not altered by antiviral therapy. Pol J Pathol. 2012;63:213-20.

36. Waluga M, Kukla M, Zorniak M, Grabiec M, Kajor M, Dyaczynski M, Kowalski G, Zadło D, Berdowska A, Kotulski R, Bułdak RJ, Sawczyn T, Waluga E, Olczyk $P$. Hartleb M. Vaspin mRNA levels in the liver of morbidly obese women with nonalcoholic fatty liver disease. Pol J Pathol. 2017;68(2):128-37.

37. Cooper, G.M. (2000) The Cell: A Molecular Approach. 2nd edition. Sunderland (MA): Sinauer Associates; 2000. The Mechanism of Oxidative Phosphorylation Available from: https://www.ncbi.nlm.nih.gov/books/NBK9885/.

38. Speijer D, Manjeri GR, Szklarczyk R. How to deal with oxygen radicals stemming from mitochondrial fatty acid oxidation. Philos Trans R Soc London B. 2014;369(1646):20130446.

39. Skonieczna M, Hejmo T, Poterala-Hejmo A, Cieslar-Pobuda A, Buldak RJ. NADPH Oxidases (NOX): Insights into Selected Functions and Mechanisms of Action in Cancer and Stem Cells. Oxid Med Cell Longev. 2017;2017:9420539 15 pages.

40. Sun Y, Zhu S, Wu Z, Huang Y, Liu C, Tang S, Wei L. Elevated serum visfatin levels are associated with poor prognosis of hepatocellular carcinoma. Oncotarget. 2017;8(14):23427-35.

41. Buldak RJ, Gowarzewski M, Buldak L, Skonieczna M, Kukla M, Polaniak R Zwirska-Korczala K. Viability and oxidative response of human colorectal HCT-116 cancer cells treated with visfatin/eNampt in vitro. J Physiol Pharmacol. 2015;66(4):557-66.

42. Buldak RJ, Polaniak R, Buldak L, Mielanczyk L, Kukla M, Skonieczna M, Dulawa-Buldak A, Matysiak N, Zwirska-Korczala K. Exogenous administration of visfatin affects cytokine secretion and increases oxidative stress in human malignant melanoma Me45 cells. J Physiol Pharmacol. 2013;64(3):377-85.

43. Kastl L, Sauer SW, Ruppert T, Beissbarth T, Becker MS, Süss D, Krammer PH Gülow K, et al. TNF-a mediates mitochondrial uncoupling and enhances ROS-dependent cell migration via NF-KB activation in liver cells. FEBS Lett. 2014:588(1):175-83.

44. Assadi S, Goodarzi MT, Saidijam M, Karimi J, Azari RY, Farimani AR, Salehi I. Resveratrol attenuates visfatin and vaspin genes expression in adipose tissue of rats with type 2 diabetes. Iran J Basic Med Sci. 2015;18:537-43.

45. Kiluk P, Baran A, Flisiak I. Role of omentin and vaspin in metabolic diseases in association with psoriasis. Dermatol Rev. 2017;104(5):519-28.

46. Mihanfar A, Rahmati-Yamchi M, Mota A, Abediazar S. Pilehvar-Soltanahmadi $Y$, Zarghami N. serum levels of Vaspin and its correlation with nitric oxide in type 2 diabetic patients with nephropathy. Curr Diabetes Rev. 2017;14(2): $162-7$.

47. Sharma JN, Al-Omran A, Parvathy SS. Role of nitric oxide in inflammatory diseases. Inflammopharmacology. 2007;15(6):252-9.

48. Fabregat I. Dysregulation of apoptosis in hepatocellular carcinoma cells. World J Gastroenterol. 2009:15(5):513-20.

49. Polyzos SA, Kountouras J, Polymerou V, Papadimitriou KG, Zavos C, Katsinelos P. Vaspin, resistin, retinol-binding protein-4, interleukin-1a and interleukin-6 in patients with nonalcoholic fatty liver disease. Ann Hepatol. 2016:15(5):705-14

50. Spahis S, Delvin E, Borys J-M, Levy E. Oxidative Stress as a Critical Factor in Nonalcoholic Fatty Liver Disease Pathogenesis. Antioxid Redox Signal. 2017:26(10):519-41.

51. Heiker JT, Klöting N, Kovacs $P$, Kuettner EB, Sträter N, Schultz S, Kern M, Stumvoll M, Blüher M, Beck-Sickinger AG. Vaspin inhibits kallikrein 7 by serpin mechanism. Cell Mol Life Sci. 2013;70(14):2569-83.

\section{Publisher's Note}

Springer Nature remains neutral with regard to jurisdictional claims in published maps and institutional affiliations. 